\title{
PRAĆENJE I OBEZBJEĐIVANJE KVALITETA PODATAKA U UZAJAMNOJ BIBLIOGRAFSKOJ BAZI: SLOVENSKA ISKUSTVA
}

\author{
Doc. dr. Ema Dornik, bibliotekarka višja svetnica / Librarian Senior Advisor \\ Institut informacijskih znanosti, Maribor, Slovenija \\ The Institute of Information Science, Maribor, Slovenia \\ ema.dornik@izum.si
}

\begin{abstract}
Sažetak
$\mathrm{U}$ radu predstavljamo slovenska iskustva u praćenju prirasta bibliografskih zapisa te kvaliteta podataka u uzajamnoj bibliografski bazi podataka COBIB.SI. Predstavljeni su podaci o prirastu uzajamne baze za period od 2014. do 2018. godine. Osim kvantitativnih podataka, predstavljene su aktivnosti u okviru sistema za obezbjeđivanje višeg kvaliteta uzajamne baze. Predstavljeni su podaci o praćenju rada katalogizatora početnika (novajlija), kako prije, tako i nakon dobivanja dozvole za uzajamnu katalogizaciju. Predstavljene su i aktivnosti tekućeg praćenja kvaliteta bibliografskih zapisa s akcentom na praćenju kvaliteta bibliografskih zapisa s nedostacima istog tipa, te praćenje zapisa tzv. dnevne produkcije. Počeci imaju osnovu u individualnom pristupu, međutim, taj se pristup pokazao kao neefikasan. Analize nekih izvedenih aktivnosti pokazale su da je danas u prosjeku otklonjeno preko $60 \%$ otkrivenih grešaka. Veliki je odaziv katalogizatora, a također su dobro prihvatili ove aktivnosti. Opažamo da putem obavještavanja također skrećemo pažnju na određene novosti ili pomagala prilikom rada na katalogizaciji. Na osnovu analiza prirasta i praćenja trendova, ubuduće ćemo lakše planirati eventualne intervencije u bazi podataka, izvoditi dodatne analize podataka, planirati nove dopune programske opreme itd. Nadamo se da će naše iskustvo dobro doći i ostalim učesnicima u mreži COBISS.net.
\end{abstract}

Ključne riječi: COBISS, COBIB.SI, uzajamna katalogizacija, bibliografski zapisi, kvalitet

\section{Uvod}

Uzajamna katalogizacija omogućuje racionalnu podjelu rada i uštedu kod zahtjevnog postupka obrade bibliotečke građe i vođenja kataloga. Za svaku jedinicu dovoljna je samo obrada na jednom mjestu, nakon čega je zapis, preko uzajamne bibliografsko-kataložne baze podataka COBIB, dostupan svim učesnicima u sistemu i u mreži COBISS.net (Vzajemna katalogizacija 2018). Baze podataka sadrže bibliografske zapise za različitu vrstu građe (monografske i serijske publikacije, integrativne izvore, članke i druge sastavne dijelove), za potrebe vođenja osobnih bibliografija autora, kao i zapise za izvedena djela. Akcenat je na uvažavanju standarda i priručnika (Dimec 2001; Turner 2010; COMARC/A 2019; COBMARC/B 2019), a susrećemo se i s brojnim novim izazovima, jer se potrebe i namjena kataloga mijenjaju u skladu s promjenama u okruženju, s potrebama korisnika, povećava se opseg i način publiciranja, što sve skupa predstavlja dodatne nove izazove za bibliografski opis.

\section{Katalogizacija}

U Sloveniji katalogizacija ima bogatu tradiciju, a u uzajamnoj katalogizaciji danas učestvuje 301 biblioteka (COBISS3 - Knjižnice 2019). U sistemu COBISS.net, kao organizacijskom modelu povezivanja biblioteka, krajem 2018. godine učestvovala je 1.321 biblioteka (COBISS.Net v številkah 2019), u a COBISS.SI bilo je uključeno 910 punopravnih biblioteka članica (IZUM 2019). Riječ je o nacionalnom bibliotečkom informacijskom sistemu s uzajamnom katalogizacijom, uzajamnom bibliografskokataložnom bazom podataka COBIB.SI i lokalnim bazama podataka biblioteka učesnica, bazom podataka o bibliotekama COLIB, normativnom bazom podataka CONOR te s brojnim drugim funkcijama (Organizacijski model 2018). Za mrežu COBISS. net (2019) značajna je 2003. godina, kada je potpisan Sporazum o uspostavljanju mreže COBISS. net i slobodnom protoku bibliografskih zapisa koji se kreiraju u autonomnim bibliotečkim informacijskim sistemima država učesnica. Podaci o broju 
uključenih biblioteka, o tome koliko njih koristi segment COBISS3/Katalogizacija i koliko svaka država ima katalogizatora s dobivenom dozvolom za uzajamnu katalogizaciju monografskih publikacija te aktivnim bar jednim korisničkim imenom za rad u sistemu, predstavljen je u Tabeli 1 (podaci prikupljeni na dan 6. 11.2019. godine).
Preko međunarodne saradnje, uzajamna katalogizacija postala je još racionalnija, a njena dodana vrijednost još veća. U periodu od 11. 11. 2004. do 31. 12. 2018. između sistema razmijenjeno je 739.416 bibliografskih zapisa, od toga 65.905 u 2018. godini.

Tabela 1: COBISS.net: broj biblioteka i korišćenje segmenta COBISS3/Katalogizacija

\begin{tabular}{|l|c|c|c|}
\hline Država & Br. biblioteka & COBISS3/Katalogizacija & Br. katalogizatora* \\
\hline Albanija & 32 & 32 & 60 \\
\hline Bugarska & 2 & 2 & 79 \\
\hline Bosna i Hercegovina & 86 & 77 & 221 \\
\hline Crna Gora & 39 & 31 & 718 \\
\hline Sjeverna Makedonija & 60 & 15 & 695 \\
\hline Slovenija & 917 & 301 & 865 \\
\hline Srbija & 217 & 197 & 2.109 \\
\hline Ukupno & 1.353 & 655 & 71 \\
\hline
\end{tabular}

Legenda: br. - broj; * - katalogizatori s dobivenom dozvolom za uzajamnu katalogizaciju monografskih publikacija (DVKA) i aktivnim korisničkim imenom

\section{Prirast bibliografskih zapisa}

U Sloveniji postoji 695 vlasnika aktivne dozvole za uzajamnu katalogizaciju monografskih publikacija s bar jednim korisničkim imenom. U 2018. godini, njih 585 aktivno je učestvovalo s bar jednim kreiranim bibliografskim zapisom. Biblioteke su u 2018. godini u COBIB.SI ukupno unijele 167.550 bibliografskih zapisa, a u normativnu bazu CONOR.SI još 57.368 normativnih zapisa za osobna imena i korporacije (IZUM 2019).

U Sloveniji još od 2014. godine pratimo prirast COBIB.SI na dnevnom, mjesečnom i godišnjem nivou (Dornik 2015; 2016; 2018; 2019; 2019a). Praćenje prirasta tokom petogodišnjeg perioda pokazuje kretanje prirasta bibliografskih zapisa i predstavljeno je na Slici 1. U prikaz su uključeni samo podaci za bibliografske zapise koje su u COBIB.SI unijeli katalogizatori. Podatke smo prikupljali ručno za svaki mjesec, a pri tom su uvažavani svi dani u godini. Podaci (apsolutni brojevi) mogu se razlikovati od današnjeg stanja broja zapisa. COBIB.SI je "živa" bibliografska baza i broj kreiranih zapisa se mijenja, npr. brisani su duplirani zapisi, a iz prikaza su također izostavljeni bibliografski zapisi koji su programski uključeni u COBIB.SI.

Na Slici 1 uočljiva je sezonska komponenta, a prisutno je i nekoliko slučajnih komponenti koje su utjecale na odstupanja. Ne možemo zanemariti ni činjenicu da slovenski katalogizatori u uzajamni katalog unose zapise i tokom neradnih dana. U 2014. i 2018. godini svakog dana u godini bilježimo prirast bibliografskih zapisa (Dornik 2015; 2019a). U 2015. 2016. i 2017. godini samo tokom 7 neradnih dana ne bilježimo prirast (Dornik 2016; 2018; 2019; 2019a).

Prilikom praćenja numeričkog godišnjeg prirasta bibliografskih zapisa svjesni smo da kvalitet bibli-

Slika 1: COBIB. SI: godišnji prirast bibliografskih zapisa po mjesecima, 2014.-2018. (izvor: Dornik 2019a)

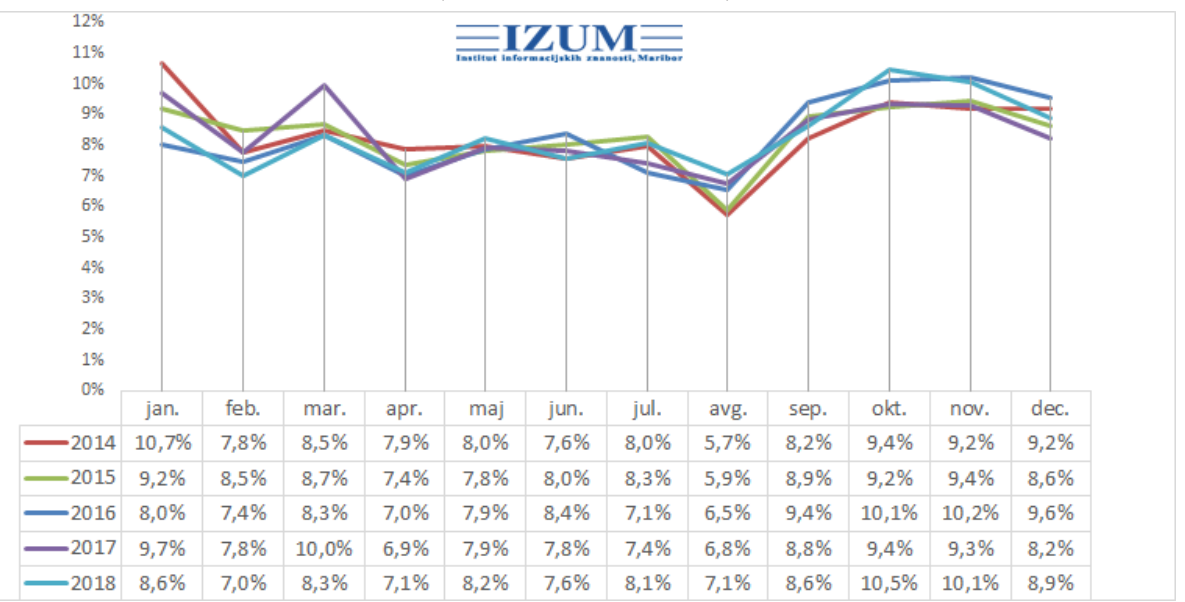


ografskih zapisa mora biti važniji od kvantiteta. U tu svrhu, Izum izvodi aktivnosti koje su dio sistema obezbjeđivanja kvaliteta bibliografskih i normativnih zapisa u COBIB.SI (Dornik et al. 2017).

\section{Sistem obezbjeđivanja kvaliteta}

Obezbjeđivanje kvaliteta od izuzetnog je značaja za uzajamnu katalogizaciju, jer bibliografski zapisi ne predstavljaju samo podatke za upotrebu u "lokalnom" bibliotečkom katalogu. Kvalitet rada katalogizatora veoma je kompleksan, a posljedično ima utjecaj na usluge koje su na raspolaganju korisnicima biblioteka u biblioteci i izvan nje (Dornik 2017). Ne može se previdjeti da sistem obezbjeđivanja kvaliteta bibliografskih i normativnih zapisa u COBIB.SI ima više slojeva. Razumijevanje i vrednovanje kvaliteta podataka uslovljavaju međusobno prepleteni činioci, poput krajnjih korisnika, jedinstvene obrade, organizacije / racionalizacije radnog procesa, katalogizatora i tehnologije, odnosno programske opreme. Zato se zauzimamo za pristup koji govori o tome da kvalitet podataka u katalogizaciji treba razumjeti kontekstualno (Badovinac 2018). Pojam kvalitet podataka razvijao se skupa s oblikovanjem katalogizacije i bibliografske kontrole. U američkom prostoru prepoznat je još u 19. stoljeću, a sredinom 20. stoljeća ispostavlja se u kontekstu produktivnosti; u 70-im i 80-im godinama prošlog stoljeća, uporedo s pojavom kooperativnih mreža, najviše pažnje dobio je u okviru baza podataka (Badovinac 2017). Kvalitet bibliografskih podataka u sistemima uzajamne katalogizacije neraskidivo je povezan (i) s kataloškim pravilima. Bitna je svijest o tome da su znanje, iskustva i sistematičan rad katalogizatora od ključnog značaja za nivo kvaliteta sistema kao cjeline. Za kvalitet zapisa u prvom redu su odgovorni sami katalogizatori, ali i rukovodstvo biblioteka koje je dužno da prati rad svojih katalogizatora (Dornik et al. 2017). Osim katalogizatora i biblioteka, o praćenju kvaliteta bibliografskih i normativnih zapisa u COBIB.SI brinu i u Narodnoj i univerzitetskoj biblioteci u Ljubljani (NUK) i u Institutu informacijskih znanosti u Mariboru (IZUM).

\section{Aktivnosti na obezbjeđivanju kvaliteta}

U okviru Izuma funkcionira sektor Bibliografska kontrola s radnom skupinom za kvalitet. Još uvijek razvijamo i tražimo metode $\mathrm{i}$ aktivnosti za najbolji sistem za obezbjeđivanje kvaliteta COBIB.SI.

U sektoru Bibliografska kontrola izvode se aktivnosti koje podižu kvalitet podataka uzajamne bibliografsko-kataložne baze COBIB. Riječ je o sljedećim aktivnostima:

- obrazovanje i osposobljavanje kandidata katalogizatora za dobivanje pojedinih dozvola ( $\mathrm{u}$ suradnji s NUK-om);

- praćenje rada katalogizatora početnika nakon dobivanja pojedine dozvole;

- periodične formalne provjere 100 slučajno programski izabranih bibliografskih zapisa i pripadajućih normativnih zapisa, koje se izvode jednom godišnje (u suradnji s NUK-om);

- tekuće praćenje kvaliteta zapisa:

- identifikacija zapisa s istim tipom nedostataka,

- praćenje kvaliteta zapisa dnevne produkcije;

- druge stalne aktivnosti (npr. telefonska podrška, redakcija normativnih baza);

- povremene aktivnosti, odnosno projekti (npr. prelazak na COBISS3/Katalogizaciju).

\section{Obrazovanje i osposobljavanje kandidata katalogizatora za dobivanje pojedine dozvole}

Obrazovanju i osposobljavanju katalogizatora poklanjamo veliku pažnju. Briga za kvalitet odvija se, kako prije, tako i nakon dobivanja pojedine dozvole za uzajamnu katalogizaciju. U okviru te aktivnosti izvode se pregledi i savjetovanje kod zapisa koji su uslov za dobivanje dozvola za uzajamnu katalogizaciju, kod tzv. testnih zapisa. Detaljne informacije za period od 2014. do 2018. godine predstavljene su u Tabeli 2 .

Tabela 2: Pregledi testnih zapisa za dobivanje dozvole za uzajamnu katalogizaciju monografija (DVKA), za period 2014-2018.

\begin{tabular}{|c|c|c|c|}
\hline Godina & Br. pregleda & Br. pregledanih zapisa & Br. kandidata \\
\hline 2014. & 24 & 720 & 16 \\
\hline 2015. & 32 & 960 & 17 \\
\hline 2016. & 30 & 900 & 16 \\
\hline 2017. & 22 & 660 & 11 \\
\hline 2018. & 39 & 1.170 & 23 \\
\hline
\end{tabular}

Legenda: br. - broj 


\section{Praćenje rada katalogizatora početnika nakon dobivanja pojedine dozvole}

Nakon dobivanja dozvole za uzajamnu katalogizaciju, katalogizatoru početniku (novajliji) nudimo stručnu pomoć i povratnu informaciju o pregledanim zapisima koji su kreirani u određenom vremenskom periodu u okviru pojedine dobivene dozvole. Katalogizator ima status početnika prvih 12 mjeseci nakon datuma dobivanja pojedine dozvole za uzajamnu katalogizaciju. U okviru postojećih dozvola za uzajamnu katalogizaciju, pojedinac može pet puta biti katalogizator početnik (Dozvola A - za uzajamnu katalogizaciju monografskih publikacija, Dozvola B1 - za uzajamnu katalogizaciju sastavnih dijelova; Dozvola B2 - za uzajamnu katalogizaciju kontinuiranih izvora; Dozvola C - za uzajamnu katalogizaciju neknjižne građe; Dozvola D - za uzajamnu katalogizaciju antikvarne građe). Katalogizator početnik na raspolaganju ima i mentora, obično katalogizatora koji je zaposlen $\mathrm{u}$ istoj biblioteci $\mathrm{u}$ kojoj radi početnik. Ako biblioteka ima samo jednog katalogizatora (samo početnika), o mentorstvu brinu NUK ili IZUM.

Svrha toga da u Izumu posebno pratimo početnike ogleda se u tome da katalogizatorima pomognemo $\mathrm{u}$ početku njihovog rada s određenom vrstom građe te da ih upozoravamo na eventualne greške do kojih može doći zbog neiskustva. Zapise svakog katalogizatora početnika pregledamo dva puta, prvi put nakon pola godine, a drugi put nakon prve godine od dobivanja pojedine dozvole za uzajamnu katalogizaciju. U model polugodišnjeg pregleda uključujemo najviše 25 zapisa izabranih po metodi slučajnog uzorka, a pregledamo ih bez predloška. Specifičnost pregleda ogleda se u tome da pažnju usmjeravamo na nedostatke koje smo opazili prilikom osposobljavanja za dobivanje pojedine dozvole. O rezultatima pregleda zapisa, katalogizatore obavještavamo elektronskom poštom, a dodatno savjetovanje je na raspolaganju i telefonom.

Podatke o praćenju početnika (novajlija) u periodu od 2015. do 2018. godine saželi smo u Tabeli 3 .

\section{Periodično provjeravanje 100 bibliografskih zapisa izabranih po metodi slučajnog uzorka}

Aktivnost periodične provjere 100 bibliografskih zapisa godišnje odvija se u suradnji s NUK-om još od 2005. godine. Ovlašteni predstavnici obje ustanove pregledaju zapise pomoću predloška (izvora) i potom ih ocijene. Vlasnike dozvola čiji bibliografski i pripadajući normativni zapisi nisu u skladu s kataloškim pravilima, odnosno pravilima COMARC formata, NUK i IZUM pismeno upozoravaju na greške. Opšti sažetak o pregledu zapisa javno se objavljuje u spisku novosti na internetskoj stranici COBISS.SI, i to dva puta godišnje, svaki put po 50 zapisa (Kavčič 2012).

\section{Tekuće praćenje kvaliteta}

Metodom tekućeg praćenja kvaliteta COBIB.SI pokušavamo pronaći i otkloniti teškoće i nedostatke u katalogizaciji građe. Aktivnosti se obično odvijaju u suradnji s katalogizatorima kojima šaljemo prijedloge popravki. U okviru tekućeg praćenja trenutno izvodimo dvije aktivnosti:

1. Identifikacija bibliografskih zapisa s nedostacima istog tipa

Tokom praćenja kvaliteta uzajamne baze podataka često pronalazimo greške koje se ponavljaju. Da bismo otkrili uzroke za nastanak tih grešaka, potrebno je da uradimo analizu na većem uzorku zapisa $\mathrm{s}$ istim tipom nedostataka. Izbor zapisa obično je limitiran na određeni vremenski period (npr. posljednja godina ili više), a pregled zapisa izvodi se bez predloška (izvora).

U okviru ove aktivnosti, u periodu od 1. 1. 2016. do 31. 12. 2018. godine obrađeno je preko 60 grešaka, kako u bibliografskim tako i u normativnim zapisima. Evo nekoliko generičkih grešaka: pogrešna upotreba znakova (npr. znak za sortiranje), pogrešni kodovi u potpoljima, polja koja nedostaju, pogrešan redoslijed potpolja, neslaganje podataka itd. O greškama smo e-poštom obavještavali posljednjeg redaktora ili kreatora zapisa (na dan obuhvata podataka) ili kontakt osobu za COBISS, ako korisničko ime više nije aktivno.

Tabela 3: Praćenje rada katalogizatora početnika (2014-2018)

\begin{tabular}{|c|c|c|c|c|}
\hline Godina & Br. pregleda & Br. pregledanih zapisa & Br. novajlija & Br. biblioteka \\
\hline 2014. & $/$ & 303 & 17 & $/$ \\
\hline 2015. & 60 & 514 & 46 & 41 \\
\hline 2016. & 77 & 723 & 44 & 37 \\
\hline 2017. & 66 & 457 & 36 & 35 \\
\hline 2018. & 45 & 370 & 31 & 28 \\
\hline
\end{tabular}

Legenda: br. - broj; / - ne postoji podatak 
Predstavljamo primjer pogrešne upotrebe znaka za sortiranje u blokovima 2 i 5 . U analizu smo uključili podatke iz potpolja: 200a,e,d,i,h; 210c; 225a,v; 500a; 510a; 517a; 530a; 540a, jer greške posljedično imaju utjecaj, kako na rezultate pretraživanja, tako i na ispise. Zbog toga smo aktivnost više puta ponovili (2015, 2017. i 2018. godine). Ručno smo pregledali podatke iz izabranih potpolja, a pri tom su nam pomagali prilagođeni ispisi prikaza rezultata pretraživanja. Podatke zatim prenosimo u Excel, čije nam različite funkcije pomažu prilikom pregledanja podataka. Iz analize smo izostavili sistemski unesene zapise.

Katalogizatorima koje smo obuhvatili pregledom i ustanovili (eventualne) greške elektronskom poštom šaljemo zahtjev za pretraživanje kojim smo u uzajamnoj bazi potražili bibliografske zapise, npr.: "U komandnom načinu pretraživanja, u polje zahtjev za pretraživanje upišite: $\mathrm{dm}=20100101: 20191024$ not cr=knt izum_not ti $={ }^{*} \mathrm{C} \# *$ or ${ }^{*} \mathrm{C} \# *$ or ${ }^{*} \mathrm{~F} \# *$ or $* \mathrm{~F}$ $\left.\#^{*}\right)$ and $\mathrm{cr}, \mathrm{re}=$ akronim uporabniško ime*, a u polje skeniranje niz za pretraživanje: $200 \mathrm{a}={ }^{*} \#^{*} \# *$ \&or $200 \mathrm{e}=* \#^{*} \# *$ \& or $200 \mathrm{~d}=* \# * \# *$ \& or $200 \mathrm{i}=* \#^{*} \# *$ \& or $210 \mathrm{c}=* \# * \# *$ \&or $215 \mathrm{i}=* \#^{*} \#^{*} *$ \&or $215 \mathrm{~h}=* \#^{*} \# *$ \&or

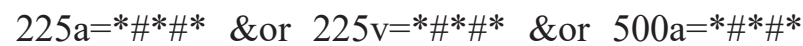
\&or $510 \mathrm{a}=* \# * \# *$ \& or $517 \mathrm{a}=* \# * \# *$ \& or $530 \mathrm{a}=* \# * \# *$ \&or $540 \mathrm{a}=* \# * \# * "$. Tokom svoga rada opazili smo da mnogi katalogizatori ne vole ovakvu vrstu pretraživanja. Zbog toga im dodatnu pomoć nudimo pismeno ili telefonom.

2. Praćenje kvaliteta zapisa dnevnog prirasta

Kod ove aktivnosti pregledamo zapise koji su kreirani određenog dana (tzv. dnevna produkcija). Os- novna svrha ovakvog pregleda je tekuće otklanjanje nedostataka u novijim zapisima, a uveden je sredinom 2015. godine. Ovakav pregled zasniva se na tekućem praćenju kvaliteta bibliografskih zapisa tokom kojeg jednom nedjeljno obuhvatamo uzorak od slučajnih $10 \%$ zapisa kreiranih određenog dana. Uzorke određujemo pomoću Excelove funkcije $=$ RANDBETWEEN. Prilikom pregleda zapisa konsultujemo Kriterije za ocjenjivanje bibliografskih $i$ normativnih zapisa u COBISS.SI (Kriteriji 2013), pri čemu smo koncentrirani na polazišta bibliografskih formata COMARC/B Format za bibliografske podatke (2019) i COMARC/A Format za normativne podatke (2019), npr. da li su podaci upisani u odgovarajuća polja. U slučaju većih nedostataka, kreatoru ili redaktoru zapisa e-poštom šaljemo preporuke za dopune. Poslate preporuke oblikovane su samo na osnovu strukture podataka u zapisu (tj. bez prijedloška). Katalogizatori ih provjeravaju i uvažavaju, s obzirom na konstatovano stvarno stanje $u$ primarnom izvoru. U preporuke su dodate reference, tako da katalogizator, prilikom redakcije zapisa u kataloškim pravilnicima i priručnicima te drugoj objavljenoj dokumentaciji, može provjeriti sadržaj primjedbi.

U periodu promatranja (2016-2018) u okviru ove aktivnosti uzorkom je obuhvaćeno i pregledano 7.425 bibliografskih zapisa, u $1.718(23,1 \%)$ zapisa uočeni su veći nedostaci, na šta smo upozorili 706 katalogizatora. Detaljni podaci predstavljeni su na Slici 2.

Slika 2: Praćenje kvaliteta zapisa u okviru dnevnog prirasta (izvor: Dornik 2019b)

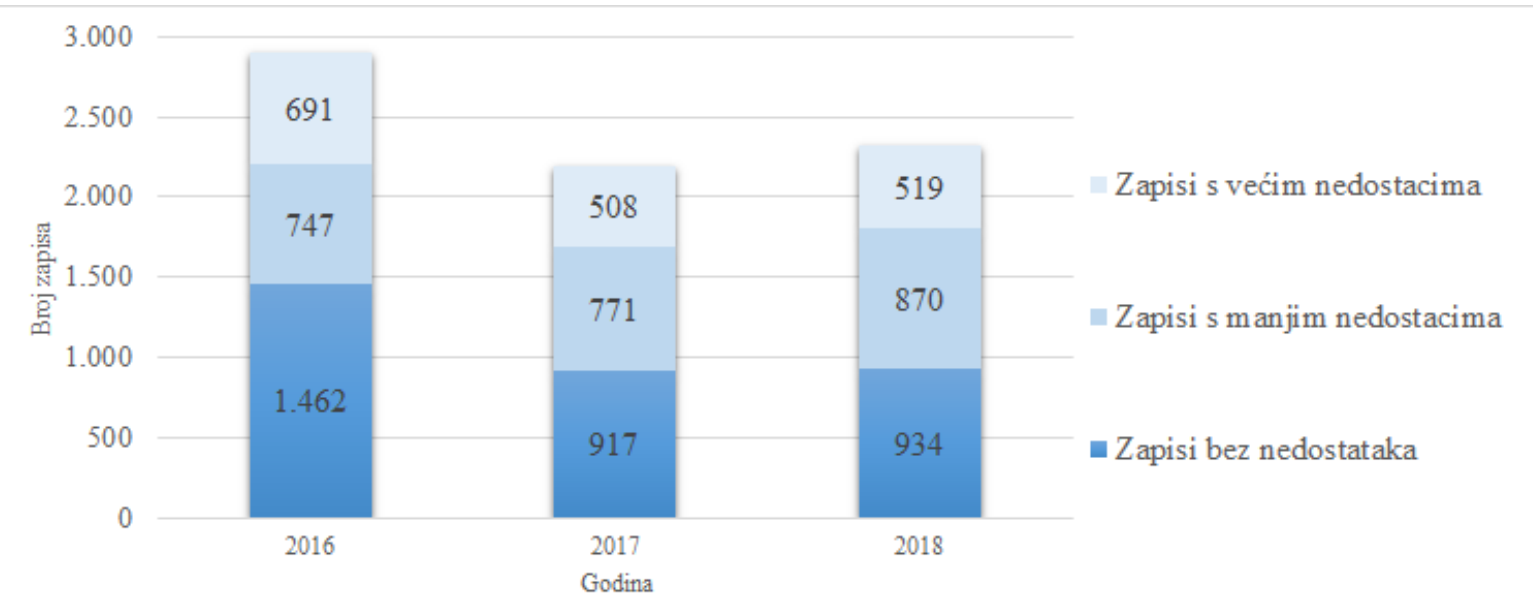

\section{Druge stalne aktivnosti}

U zadatke radne grupe spada i telefonska pomoć katalogizatorima kod sadržinskih pitanja, kao i tehnička pomoć prilikom upotrebe programske opreme COBISS3/Katalogizacija. Također, prikupljamo, provjeravamo i posredujemo poruke o nedosljednostima u zapisima koje dobijamo od krajnjih COBI-
SS korisnika i/ili od samih katalogizatora (Dornik et al. 2017; Dornik 2019b). U odjeljenju za kvalitet rade 4 suradnice koje su u periodu od 2016. do 2018. godine zabilježile više od 2.200 riješenih zahtjeva korisnika koji su stigli elektronskom poštom ili telefonskim pozivima. 


\section{Diskusija}

Svjesni smo da ne možemo doći do efekata kvalitetnog rada katalogizatora ako kvalitet ne mjerimo sistematično i ako ne istražujemo činioce koji ga uslovljavaju. Praćenje i obezbjeđivanje višeg kvaliteta podataka COBIB.SI u većini slučajeva zasniva se na ručnoj analizi. Naši počeci bili su zasnovani na individualnom pristupu, uz posredovanje spiskova zapisa s greškama i uz telefonske kontakte, međutim, taj se pristup pokazao kao veoma neefikasan. Ta su iskustva pokazala da posredovanje spiskova sa zapisima koji sadrže greške nije dobar, jer su katalogizatori otklonili samo greške u zapisima na koje smo ih upozorili, a ostale eventualne greške sami nisu opazili, a nisu ih ni potražili. U želji da otklonimo što više grešaka i da putem obavještavanja također skrenemo pažnju, npr. na određene novosti ili na pomoćna sredstva u radu katalogizatora, pažnju smo usmjerili na same greške, a ne na osobe, odnosno katalogizatore. U slučajevima kada je to moguće, npr. kod praćenja zapisa s nedostacima istog tipa, danas posredujemo niz za pretraživanje i e-obavještavanjem dosežemo veći broj katalogizatora. Posljedično, također očekujemo otklanjanje grešaka u većoj mjeri i u većem opsegu. Uprkos praćenju pojava grešaka u zapisima kreiranim u novije vrijeme, može se dogoditi da neko od korisničkih imena više nije aktivno (npr. promjena posla, odlazak u mirovinu itd.). U takvim slučajevima obavještenje posredujemo osobi biblioteke zaduženoj za kontakt i molimo je za pomoć kod pregleda zapisa i otklanjanja eventualnih grešaka.

U proteklim analizama izvođenja naših aktivnosti za obezbjeđivanje višeg kvaliteta bibliografskih podataka (Dornik et al. 2017; Badovinac 2019; Dornik 2019b), ustanovili smo da su naše aktivnosti doprinijele identifikaciji i otklanjanju nekih grešaka, međutim, naše su aktivnosti još uvijek prilično fragmentirane. Opazili smo da je odziv katalogizatora dobar $(80 \%)$, a greške se otklanjaju u prosjeku više od $60 \%$. Pokazalo se, također, da smo dosegli veći odziv kod katalogizatora u slučajevima višestrukog upozoravanja na isti tip greške u različitim vremenskim periodima, odnosno takve su se greške u bazi otklanjale u većem procentu (Badovinac 2019; Dornik 2019b).

Eventualno otklanjanje svih grešaka u bazi predstavlja zahtjevan zadatak, jer se kataloška pravila i uputstva vremenom mijenjaju. Takođe se pojavljuju situacije da katalogizatori, koji su nekada kreirali zapise, više nemaju aktivna korisnička imena, da stariji zapisi nisu jednako aktualni kao noviji zapisi itd. Znak za sortiranje nije se promijenio te je zato otklanjanje takve "tehničke" greške suštinski jednostavnije, međutim, ne može se riješiti eventualnim programskim rješenjima. Iskazalo se da pogrešnu upotrebu znaka za sortiranje katalogizatori više ne ponavljaju, odnosno da se pojava greške bitno smanjila.

Preglednost naših aktivnosti također predstavljamo na način koji omogućuje da se sve naše izvedene $\mathrm{i}$ zaključene aktivnosti i podaci o praćenju kvaliteta COBIB.SI bilježe u interni registar obezbjeđivanja kvaliteta COBIB.SI. Taj je registar na raspolaganju svakom katalogizatoru, odnosno registriranom korisniku u okviru Portala obrazovanje IZUM, pod Dozvole za uzajamnu katalogizaciju, Pregled mojih aktivnosti.

\section{Zaključak}

Razvoj informacijskog društva zasnovan je na informacijama i znanju koje je zabilježeno u bazama COBISS.net, a istovremeno ti podaci predstavljaju i odraz tog društva. Želimo naglasiti da rad katalogizatora ima veliki utjecaj na upotrebljivost podataka. Ne možemo zaobići činjenicu da smo početkom 2019. godine u lokalnim bazama COBISS.SI zabilježili 16-milioniti zapis, a sredinom 2019. godine u lokalnim bazama COBISS.net 29-milioniti zapis. Smatramo da to također ukazuje na izuzetan značaj ove mreže za cjelokupnu regiju.

$\mathrm{Na}$ osnovu rezultata analiza tekućeg praćenja kvaliteta, u sektoru Bibliografska kontrola, oblikujemo prijedloge za nova programska rješenja, dopune u dokumentaciji itd. $\mathrm{Na}$ osnovu analiza prirasta $\mathrm{i}$ praćenja trendova, ubuduće ćemo lakše planirati eventualne intervencije u bazama podataka, izvoditi dodatne analize podataka, planirati nove aktivnosti kod dopunjavanja programske opreme itd. Želimo uvesti cjelovitiji pristup obezbjeđivanju kvaliteta podataka i u izvođenje aktivnosti uključiti katalogizatore te proizilaziti iz njihovih potreba i načina rada.

Kod katalogizatora smo naišli na dobar odaziv te zato ocjenjujemo da i sami katalogizatori u COBISS sistemu shvataju da postoji potreba za (uzajamnim) katalogom s kvalitetnim podacima. Važno je razumjeti da će aktivnosti i akcije donijeti dobre rezultate samo u slučaju da u tome aktivno učestvuju svi učesnici sistema. Veliki učinak i doprinos ima i permanentno obrazovanje i dodatno osposobljavanje katalogizatora.

Kvalitetni bibliografski podaci, kao posljedica dobrog, savjesnog i stručnog rada katalogizatora, predstavljaju blagodet za sve nas. Konstatacije, proizašle iz praćenja kvaliteta zapisa, pomažu svima koji učestvuju u kooperativnom bibliografskom sistemu i servisima. Nadamo se da će naša iskustva dobro doći svima koji učestvuju u mreži COBISS.net. 


\section{Literatura}

- Badovinac, Branka. 2017. "Izhodišča za proučevanje kakovosti podatkov $\mathrm{v}$ bibliografskih in normativnih zapisih: kakovost podatkov v kontekstu in raziskovalne usmeritve v katalogizaciji” Knjižnica 61(1-2): 119-154.

- Badovinac, Branka. 2018. "Nabor dimenzij za opredelitev kakovosti podatkov v bibliografskih in normativnih zapisih" Organizacija znanja 23(1-2): 2-10.

- Badovinac, Branka. 2019. "Pikice in vejice' pod drobnogledom: spremljanje kakovosti zapisov v letu 2018" Blog COBISS. http:// blog.cobiss.si/2019/05/27/pikice-in-vejice-poddrobnogledom/\#more-2126 Datum pristupa 12. 11. 2019.

- “COBISS.Net v številkah”. 2019. Maribor: Institut informacijskih znanosti. https://www.cobiss.net/doc/ Stat_kazalci_2018.pdf Datum pristupa 12. 11. 2019.

- “COBISS3 - Knjižnice”. 2019. Maribor: Institut informacijskih znanosti. http://home.izum.si/cobiss/ cobiss3/. Datum pristupa 12. 11. 2019.

- "COMARC/A - format za normativne podatke". 2019. Maribor: Institut informacijskih znanosti. https://home.izum.si/izum/e-prirocniki/2 COMARC_A/Cel_2_COMARC_A.pdf. Datum pristupa 12.11. 2019.

- "COMARC/B - format za bibliografske podatke”. 2019. Maribor: Institut informacijskih znanosti. https://home.izum.si/izum/e-prirocniki/1 COMARC_B/Cel_1_COMARC_B.pdf. Datum pristupa 12.11.2019.

- Dimec, Zlata, Hočevar, Matjaž, i Irena Kavčič, ur. 2001. Prekat: priročnik za enostavno uporabo katalogizacijskih pravil. Ljubljana: Narodna in univerzitetna knjižnica.

- Dornik, Ema, Branka Badovinac, Jelka Kos, i Brigita Farkaš. 2017. "Sistem zagotavljanja kakovosti COBIB.SI: izbrane aktivnosti za leto 2016" Knjižnica 61(1-2): 191-205.

- Dornik, Ema. 2015. "COBIB.SI: prirast bibliografskih zapisov v letu 2014" Organizacija znanja 20(1): 21-26. https://www.cobiss.si/oz/HTML/ OZ_2015_1_final/24/index.html. Datum pristupa 12. 11. 2019.

- Dornik, Ema. 2016. "COBIB.SI: prirast bibliografskih zapisov v letu 2015" Organizacija znanja 21(2): 77-84. https://www.cobiss.si/oz/HTML/ OZ_2016_2_final/18/index.html. Datum pristupa 12. 11.2019 .

- Dornik, Ema. 2017. "Razsežnosti in vpliv kakovostnega dela katalogizatorjev" Blog COBISS. http:// blog.cobiss.si/2017/10/12/razseznosti-in-vpliv-kakovostnega-dela-katalogizatorjev/. Datum pristupa 15. 5. 2019.
- Dornik, Ema. 2018. "COBIB.SI: prirast bibliografskih zapisov v letu 2016" Organizacija znanja 22(1/2): 27-33. http://home.izum.si/cobiss/oz/ HTML/OZ_2017_1_2_final/30/index.html. Datum pristupa 12.11.2019.

- Dornik, Ema. 2019. "COBIB.SI: prirast bibliografskih zapisov v letu 2017" Organizacija znanja 23(1/2): 21-28. https://www.cobiss.si/oz/HTML/ OZ_2018_1_2_final/24/index.html. Datum pristupa 12. 11. 2019.

- Dornik, Ema. 2019a. "COBIB.SI: prirast bibliografskih zapisov v letu 2018" Organizacija znanja 24(1-2), u tisku.

- Dornik, Ema. 2019b. "Zagotavljanje kakovosti COBIB.SI: kako uspešni smo?” U Knjižnice - obvladovalke podatkov?" Kongres Zveze bibliotekarskih društev Slovenije, Maribor, 25.-27. september 2019, 35-50. Ljubljana: Zveza bibliotekarskih društev Slovenije.

- IZUM. 2019. Kazalci rasti. Maribor: Institut informacijskih znanosti. https://www.cobiss.si/kazalci/. Datum pristupa 12. 11. 2019.

- Kavčič, Irena. 2012. "Kakovost zapisov v vzajemni bibliografsko-kataložni bazi podatkov COBIB.SI" Knjižničarske novice 22(6): 1-19.

- Kriteriji za ocenjevanje bibliografskih in normativnih zapisov v COBISS.SI. 2013. http://home.izum. si/IZUM/program_izobrazevanja/COBISS3_Katalogizacija/Kriteriji_za_ocenjevanje_bibliografskih in_normativnih_zapisov.pdf. Datum pristupa 12. 11 . 2019 .

- "Mreža Cobiss.net”. 2019. Maribor: Institut informacijskih znanosti. https://www.cobiss.net/si/mreza-cobiss-net.htm. Datum pristupa 6. 11. 2019.

- “Organizacijski model sistema COBISS". 2018. Maribor: Institut informacijskih znanosti. https://www. cobiss.net/si/platforma-cobiss.htm\#c2. Datum pristupa 11. 11. 2019.

- $\quad$ Turner, Amy. H. 2010. "OCLC WorldCat as a cooperative catalog" Cataloging and classification quarterly 48(2-3), special iss.: 271-278.

- "Vzajemna katalogizacija (COBISS3/Katalogizacija)". 2018. Maribor: Institut informacijskih znanosti. https://www.cobiss.net/si/platforma-cobiss.htm\#c4. Datum pristupa 7. 11. 2019. 


\title{
MONITORING AND ASSURING DATA QUALITY IN THE UNION BIBLIOGRAPHIC DATABASE: SLOVENIAN EXPERIENCE
}

\begin{abstract}
This paper presents the Slovenian experience with monitoring bibliographic record growth and data quality in the COBIB.SI union bibliographic database. The data on the growth of the union database between 2014 and 2018 is shown. Apart from quantitative data, the activities within the framework of the system for assuring higher quality of the union database are presented. The data on monitoring the work of cataloguers - beginners both before and after acquiring the licence for shared cataloguing is shown. This includes the activity of simultaneous monitoring of bibliographic record quality with the emphasis on monitoring the quality of bibliographic records with shortcomings of the same type and monitoring the records of the socalled daily production. The initial individual approach later proved ineffective. Analyses of certain performed activities have shown that today more than $60 \%$ of detected errors are fixed on average. The responsiveness of cataloguers is high, and they have received the activities well. We notice that we are not only informing but also raising awareness e.g. on certain innovations or tools in the field of cataloguing. Based on growth analyses and trend monitoring it will be easier to plan possible database interventions, perform additional data analyses, plan new software updates and similar in the future. We hope our experience is welcome for all members of COBISS.net.
\end{abstract}

Keywords: COBISS, COBIB.SI, shared cataloguing, bibliographic records, quality 